УДК 07:32.019.51]:16

\title{
ЛОГІЧНІ ЗАСАДИ ПРОВЕДЕННЯ ІНФОРМАЦІЙНИХ КАМПАНІЙ В ІНФОРМАЦІЙНИХ ВІЙНАХ
}

\author{
Ігор Огірко \\ Українська академія друкарства \\ вул. Під Голоском, 19, 79020, Львів, Україна \\ e-mail:ogirko@gmail.com \\ https://orcid.org/0000-0003-1651-3612
}

Зіновій Партико

Житомирський державний університет ім. І. Франка

вул. Велика Бердичівська, 40, 10008, Житомир, Украӥна

e-mail:partyko@ukr.net

https://orcid.org/0000-0002-2315-5887

Метою статті є розроблення логічного апарату, який давав би мас-медійним теоріям змогу враховувати різну істинність одних і тих самих тверджень залежно від «контексту» повідомлення під час проведення інформаційних воєн. У літературі з логіки моделлю твердження, яка враховує «контекст» повідомлення, що змінює істинність твердження, є так звана ситуативна логіка. У статті запропоновано для тверджень в рамках ситуативної логіки обрати три перемінні: час, місце та умови. Така модифікація логіки названа логікою відносності. Запропонована модель твердження перевірена й проінтерпретована на прикладах.

Ключові слова: інформаційні кампанії, інформаційні війни, логіка, ситуативна логіка, логіка відносності.

Постановка проблеми. В інформаційних просторах держав часто мають місце ситуації, коли, наприклад, під час інформаційних воєн одна держава на рівні закону вважає якусь організацію терористичною, а інша - ні; коли воюючі сторони взаємно звинувачують одна другу в агресії, вважаючи себе миротворцем; коли одну й ту ж особу одна держава вважає героєм, а інша - злочинцем (терористом) тощо. Те саме (постійно!) маємо і в релігійному житті: який із богів є істинним (якщо він існує)? Схожі ситуації і в мистецтві, коли одні й ті ж твори мистецтва критики оцінюють діаметрально протилежними оцінками.

Дещо відмінну, але схожу за результатом ситуацію маємо й тоді, коли, маючи за вікном гарну днину, напишемо істинне твердження: Сьогодні в місті $N$ є гарна пого$\partial a$. Проте через кілька днів, коли дощитиме, це твердження стане хибним, хоча саме твердження зовсім не змінилось, залишившись таким, як і було в момент написання.

(C) Огірко I., Партико 3., 2019 
Аналогічний приклад можна подати й щодо опису якоїсь ідентичної події, істинність якої змінюється залежно від її місця (просторових координат).

У всіх цих ситуаціях виникає питання щодо істинності тверджень, які описують ці ситуації.

3 урахуванням сказаного, проблема, яка буде досліджуватися в цій статті, - це проблема істинності тверджень у повідомленнях мас-медіа (з позиції логіки).

Відповідно до визначеної проблеми, об'єктом у нашому дослідженні будуть твердження, а предметом - істинність цих тверджень у різних логічних можливих світах.

Мета дослідження. 3 урахуванням сказаного, перед дослідженням була поставлена мета розробити логічну теорію, яка давала б мас-медійним теоріям змогу при визначенні істинності враховувати «контекст» події, описаної у твердженні. Такий «контекст» (або: парадигма) є змінним і впливає на істинність твердження, тобто, кажучи іншими словами, істинність твердження залежить від цього «контексту». Таку теорію, яка враховує контекст твердження, називатимемо далі логікою відносності.

Для досягнення вказаної мети перед дослідженням було поставлено такі завдання:

- проаналізувати «контексти» в різних логічних можливих світах, які щодо істинності викликають неоднозначності;

- запропонувати формальний апарат (аксіоми, закони), який давав би змогу описувати вказані неоднозначності, враховуючи при цьому незаперечність критеріїв істини та, відповідно, існування як істинних, так і хибних тверджень;

- проінтерпретувати запропонований формальний апарат на прикладах різних ситуацій у логічних можливих світах;

- зіставити отриманий формальний апарат з іншими чинними логічними теоріями;

- визначити способи й можливість використання запропонованого формального апарату в мас-медіа.

Аналіз останніх досліджень і публікацій. У наш час у науці постульованими є поняття абсолютної та відносної істини. Зв'язок між ними реалізується в такий спосіб: абсолютну істину трактують як «недосяжний» ідеал, а відносну істину - як значення істинності твердження на певних етапах розвитку науки. При цьому ця відносна істина в часі все ближче й ближче наближається до ідеалу, або, кажучи іншими словами, ймовірність істинності такого твердження зростає. Проте логічного апарату, який реалізував би цей філософський постулат, зокрема відносність істини, логіка поки що не розробила.

На нашу думку, до проблеми відносності істини частковий стосунок має так звана ситуативна логіка, про яку свого часу писали К. Поппер [4], Н. Кортж [3] та інші західні дослідники $[1 ; 6]$. Зокрема Н. Кордж запропонував такі шаблони (схеми) розкриття суті ситуацій:

Суб’єкm А був у ситуаиіï типу C. [Цю ситуацію далі аналізують].

У ситуації типу C належсть виконати дію X. [Тут для дії X використовують механізм аргументування, зокрема й у формі обгрунтування]. 
Суб'єкти в ситуаиї̈ типу C завжди виконують дію X. [Узагальнюють виконання дії Х в часі й просторі].

Ось чому А зробив X. [Пояснення дій суб'єкта А].

Ідеї ситуативної логіки свого часу інтерпретував також російський логік А.А. Зінов'єв [10], який запропонував вважати ситуацією непорожню упорядковану множину сумісних станів предметів. При цьому ситуації різні, якщо різна упорядкованість станів; ситуації несумісні, якщо несумісним є хоча б один їх стан.

Термін ситуативна логіка поміщено також в одне $з$ довідкових видань [13].

Деякі цікаві міркування стосовно поняття відносності висловлені також у публікаціях, які охоплюють ділянку, що поєднує фізику, математику й логіку [2; 5; 7; 9; $14 ; 15]$.

Пошук перелічених вище джерел було проведено: а) в каталозі журналів та продовжуваних видань Національної бібліотеки України ім. В. І. Вернадського за ключовими словами логіка відносності, відносна логіка; б) в каталозі Російської державної бібліотеки (логика относительности, относительная логика); в) в каталогах Бібліотеки конгресу США й Британській бібліотеці (logic of relativity, relative logic).

Виділення не вирішених раніше частин загальної проблеми. Виходячи 3 аналізу літератури (див. список), закономірно припустити, що внаслідок існування в філософії понять абсолютної та відносної істини спроби створити апарат логіки відносності були здавна $[8 ; 11 ; 12]$. Проте виявити довершені й вагомі результати таких розробок, як засвідчив пошук літератури, нам не вдалось. Отже, розроблення теорії, а також створення апарату логіки відносності належить до актуальних завдань сучасної логіки.

Звертаємо увагу на те, що, називаючи нашу теорію логікою відносності, ми зовсім не маємо на увазі, що істини начебто не існує або що будь-яку істину можна перетворити на хибу. Обравши таку назву, ми лише акцентуємо увагу на тому, що істинність тверджень, крім них самих, залежить від ще кількох типових перемінних, які всі підрозумівають, але про які, як правило, не говорять, вважаючи їх очевидними, а тому й не потрібними для врахування. Ми ці очевидні перемінні будемо намагатися лише явно зафіксувати.

Методи дослідження: а) абстрагування - для виокремлення ознак істинності від досліджуваних об'єктів, що існують у логічних можливих світах; б) аналіз (традиційний) - для отримання даних з літературних джерел; в) синтез - для укладання теорії та апарату логіки відносності; г) формалізація - для запису речень природної мови у формі тверджень мовою символьної логіки; г) моделювання - для створення логічної моделі твердження; д) логічний метод - для перевірки несуперечності запропонованої теорії (внутрішньої та зовнішньої).

Поняття ситуації. Оскільки до проблеми відносності явний стосунок має поняття ситуації (M), дамо цьому поняттю таке означення: ситуація М - це дві обставини (час T i простір L), а також умова (U), які створюють контекст (парадигму) твердження, тобто

$$
\mathrm{M}=(\mathrm{T}, \mathrm{L}, \mathrm{U})
$$

Параметр часу Т може набувати таких значень (оцінок): завжди, у деяких відрізках часу, у деякий відрізок часу, у деяких точках часу, в деякій точці часу, ніколи. 
Параметр простору L може набувати таких значень (оцінок): усюди, у деяких фрагментах простору, в деякому фрагменті простору, у деяких точках простору, в деякій точияі простору, ніде.

В якості умови U в логіці відносності можна використовувати твердження різних модальних логік, наприклад акціональної (логіки дії) з предикатом бажає (має намір, хоче, планує) тощо. Можливою є й така ситуація, коли якесь твердження $є$ істинним за будь-яких умов, крім обставин.

Загалом, якщо час розглядати як один вимір, простір - як три виміри, то умову можна розглядати як п’ятий вимір.

Запис тверджень у логіці відносності. Твердження в логіці відносності збудуємо на основі тверджень традиційної двозначної логіки $з$ додаванням до нього оператора модальності. За такої будови логіка відносності належатиме до різновиду модальних логік.

Відповідно, мовою логіки предикатів будову модального твердження $\mathrm{D}\{\mathrm{D}=\mathrm{Q}$ $\left.\left[\mathrm{P}\left(\mathrm{s}, \mathrm{o}_{1}, \mathrm{o}_{2}, \mathrm{o}_{3} \ldots \mathrm{o}_{\mathrm{n}}\right)\right]\right\}$, що враховує наявність ситуації $\mathrm{M}$, запишемо так:

$$
\text { M Q }\left[\mathrm{P}\left(\mathrm{s}, \mathrm{o}_{1}, \mathrm{o}_{2}, \mathrm{o}_{3} \ldots \mathrm{o}_{\mathrm{n}}\right)\right] \text {, }
$$

де $\mathrm{M}$ - оператор модальності, що містить опис ситуації $\mathrm{M}=(\mathrm{T}, \mathrm{L}, \mathrm{U})$;

Q - квантор кількості твердження;

P - предикат твердження;

$\mathrm{s}$ - суб'єкт твердження;

$\mathrm{o}_{\mathrm{i}}$ - об'єкти твердження $(\mathrm{i}=1,2,3 \ldots \mathrm{n})$.

3 урахуванням сказаного, твердження (2) можна переписати у повній формі:

$$
(\mathrm{T}, \mathrm{L}, \mathrm{U}) \mathrm{Q}\left[\mathrm{P}\left(\mathrm{s}, \mathrm{o}_{1}, \mathrm{o}_{2}, \mathrm{o}_{3} \ldots \mathrm{o}_{\mathrm{n}}\right)\right] \text {. }
$$

Умова U, представлена як твердження, разом зі самим основним твердженням $\mathrm{D}$, ситуацію якого вона формує, утворює імплікацію:

або:

$$
\mathrm{U} \rightarrow \mathrm{D} \text {, }
$$

$$
\mathrm{U} \rightarrow \mathrm{Q}\left[\mathrm{P}\left(\mathrm{s}, \mathrm{o}_{1}, \mathrm{o}_{2}, \mathrm{o}_{3} \ldots \mathrm{o}_{\mathrm{n}}\right)\right],
$$

Така імплікація відповідно до таблиці істинності логіки висловів у традиційній логіці є хибною лише за тих умов, коли твердження U є істинним, a D - хибним (у всіх інших варіантах така імплікація є істинною).

3 розгляду умови U випливає, що якщо цілі суб'єктів різняться чи навіть діаметрально протилежні, то для таких суб’єктів істинність одних і тих самих інших тверджень може бути так само різною. Це пояснює наявність різних оцінок одних і тих самих тверджень, які використовують в інформаційних просторах держав, що перебувають у стані війни, зокрема й лише інформаційної. Тому в таких ситуаціях 3 позиції логіки доречно говорити не про істинність, а про відносну істинність аналізованих тверджень.

Інтерпретація істинності тверджень у логіці відносності. Подамо кілька прикладів.

Приклад 1. Істинність твердження Земля є пласкою залежить від часу, коли визначали його істинність: приблизно до XVI-XVII ст. це твердження вважали істинним, а після вказаної дати - хибним.

Таким чином, істинність твердження про те, що Земля є пласкою змінювалася залежно від обставин, зокрема момента часу, в який визначали істинність цього твердження. 
Приклад 2. Якщо поглянути на площину різностороннього прямокутника з різних позицій, тобто з різних точок простору (зверху, з різних боків у площині прямокутника, під різними кутами поза площиною прямокутника), то ми будемо бачити різні геометричні фігури:

- при погляді зверху й знизу під кутом 90 градусів до площини - прямокутник;

- при погляді з різних боків у площині прямокутника - дві лінії різної довжини;

• при погляді під різними кутами поза площиною прямокутника - паралелограми з різною довжиною сторін і різною величиною кутів.

Таким чином, істинність твердження про те, що Геометрична фiгура має форму хxхxхx змінюється залежно від обставин, зокрема позиції спостерігача в просторі. Приклад 3. Про одного царя розповідають таку притчу.

До изаря прийшла жінка й поскаржилася на сусідку за те, що курка сусідки видзьобала все тільки-но засіяне в землю зерно. Жінка за нанесену шкоду посварилася з сусідкою.

- Чи я права, щзо сварилася через заподіяну мені шкоду? - запитала жінка в изаря.

- Ти права, - відповів ияар.

Через кілька хвилин до изаря прибігла сусідка й сказала:

- До тебе приходила жінка, в якої моя курка видзьобала на городі зерно. Але хіба я можу прив'язати курку до себе? Чи я повинна прив'язати курку до якогось стовпия? Звісно, що ні, адже так ніхто не робить. А та жінка влаштувала мені через цее сварку. Отже, права я, щчо не прив'язала курки, а не та жінка, еге ж?

- Ти права, - відповів ијар. - Курей справді ніхто не привяязе.

Всі иі розмови чула третя жінка, яка в цей час прибирала иарські покої.

- Але ж, иарю, - зауважила третя жінка, коли дві попередні пішли, - те, щяо ти двом жінкам підтвердив їх правоту, суперечить одне одному!

- I ти також права, - відповів ццар.

У цій притчі перша жінка права, оскільки її приватну власність 3 вини іншої особи було знищено (вона права юридично). Друга жінка також права, оскільки курей на мотузок дійсно ніхто не прив'язує (права за звичаєвими правилами ведення господарства). Третя жінка права логічно, оскільки два протилежні твердження не можуть бути істинними водночас.

Таким чином, істинність твердження для кожної жінки залежить від умови, 3 позиції якої визначається істинність твердження Жінка $N \epsilon$ правою.

Приклад 4. Редактор одного американського фармакологічного журналу, який відпрацював у ньому 30 років, виходячи на пенсію, заявив:

- Якщо переглянути публікації 30-річної давності, то сьогодні приблизно про половину з них можемо сказати, що вони були хибними.

Висновки. 1. Логіка відносності є розширенням традиційної двозначної логіки. Вона не заперечує і не відкидає жодних напрацювань традиційної логіки.

2. Оскільки істинність тверджень залежить від ситуацій (тобто контексту, чи парадигми), в яких їх розглядають, то в якості параметрів ситуації доцільно використовувати час, простір й умову, які так само мають форму тверджень. 
3. Логіку відносності доцільно застосовувати в тих сферах життя суспільства, де вимушено доводиться враховувати переміщення твердження в часі, просторі й середовищі умов. До таких сфер належить інформаційний простір держави.

4. 3 позиції логіки відносності, якщо цілі суб’єктів різняться чи навіть діаметрально протилежні, то для таких суб'єктів істинність частини одних і тих самих інших тверджень так само може бути протилежною. Тому в таких ситуаціях з позиції логіки доречно говорити не про істинність, а про відносну істинність аналізованих тверджень.

5. Логіка відносності є логічним апаратом, який пояснює різні істинності одних і тих самих тверджень у мас-медіа, а тому їі доречно використовувати для пояснень та інтерпретацій у мас-меді.

\section{REFERENCES}

1. Barwise, J. The situation in logic. [S. L.] : Center for the Study of Language and Information, 1989. $328 \mathrm{p}$.

2. Jane I., Wright C. Two articles on «relativity». // Bulletin of symbolic logic. Vol. 11 (2005). № 1. P. 84-88.

3. Koertge, N. Popper's Metaphysical Research Program for the Human Sciences. // Inquiry. Vol. 18 (1975). P. 437-462.

4. Popper, K. The Poverty of Historicism. [S. L.] : Routledge, 1957. 166 P.

5. Prokhovnik S. J. The logic of special relativity. London : CUP, 1967. $138 \mathrm{p}$.

6. Syverson, P. F.; Fagin, R. An Epistemic Logic of Situations // Proceedings of the conference on theoretical aspects of reasoning about knowledge.; Theoretical aspects of reasoning about knowledge; Pacific Grove; CA, 1994; Mar, 1994. San Francisco : Morgan Kaufmann, 1994. P. 109-121.

7. The theory of relativity : principles, logic and experimental foundation. New York : Nova Science Publishers, 2014. 503 p.

8. Truth // Wikipedia [Electronic resource]. - Mode of access: URL: https:/en.wikipedia. org/wiki/Truth. Last access: 04.10.2018. Title from the screen.

9. Гулый А. М. Теория относительности - реальность или выдумка при отсутствии логики. Сумы : МакДен, 2006. 138 с.

10. Зиновьев А. А. Основы логической теории научных знаний. - Москва: Наука, 1967. - $156 \mathrm{c}$.

11. Истина // Википедия [Электронный ресурс]. - Режим доступа: URL: https:// ru.wikipedia.org/wiki/Истина. Дата доступа: 04.10.2018. Название с экрана.

12. Істина // Вікіпедія [Електронний ресурс]. - Режим доступу: URL: https:// uk.wikipedia.org/wiki/Істина. Дата доступу: 04.10.2018. Назва з екрана.

13. Кондаков, Н. И. Ситуация // Кондаков, Н. И. Логический словарь-справочник. 2-е изд., исправл. и дополн. Москва : Наука, 1975. С. 546.

14. Стрелков, В. Г. Физика и логика эфирной вселенной. Москва : [Б. И.] 2001. 247 с.

15. Штепа, В. И. Единая теория поля и вещества с точки зрения логики : физ. принципы натур. философии. 2-е изд., испр. и доп. Москва : URSS, 2006. 366 с. 


\title{
LOGIC BASIS OF INFORMATION CAMPAIGNS IN INFORMATION WAR
}

\author{
Ihor Ohirko \\ Ukrainian Academy of Printing \\ Pid Goloskom Str., 19, 79020, Lviv, Ukraine \\ e-mail:ogirko@gmail.com \\ https://orcid.org/0000-0003-1651-3612 \\ Zinovii Partyko \\ Zhytomyr Ivan Franko State University \\ Velyka Berdychivska Str. 40, 10008, Zhytomyr, Ukraine \\ e-mail:partyko@ukr.net \\ https://orcid.org/0000-0002-2315-5887
}

During the conducting of information wars, it is often arising situations when the same statements are assessed by the warring parties in a diametrically opposed manner. The assessment of such conflicting statements from the standpoint of truth is a problem that is investigated in the article.

The purpose of the article is to develop a logical apparatus that would allow mass media theories to take into account the different truths of the same statements depending of the «context» of the message.

In the literature on logic, the model of the statement that takes into account the «context» of the message, which changes the truth of the statement, is the so-called situational logic. In the article it is proposed to select three variables for statements within the framework of situational logic: time, place and conditions. In the role of such conditions, sometimes there may be goals pursued by actors, that is, the sides of information wars. Such a modification of logic is called the logic of relativity.

The proposed model of the statement is verified and interpreted in the examples.

The conclusions of the article state that the logic of relativity is an extension of the traditional two-valued logic. It is expedient to use it in those spheres of a society's life, where it is compulsory to take into account the movement of the statement in time, space and environment of conditions. Such spheres include, inter alia, information space of states. From the standpoint of the logic of relativity, if the goals of the entities are different or even diametrically opposed, then for such entities the truth of some of the same statements can be the opposite. Therefore, in such situations from the standpoint of logic it is appropriate to speak not about truth, but about the relative truth of conflicting statements.

The logic of relativity is a logical apparatus that explains the different truths of the same statements in the mass media at the time of information wars.

Key words: information campaign, information war, logic, situation logic, logic of relativity. 